\title{
Not Only on Bread and Water. The Nutrition of Prisoners in the Kingdom of Poland in the 19th Century
}

\author{
Anna Trojanowska* \\ Department of Polish Academy of Sciences, Poland
}

Keywords: $19^{\text {th }}$ century; Prisoner nutrition; Rumford soup

ISSN: 2640-9208

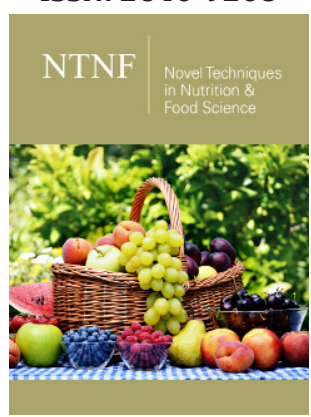

${ }^{* 1}$ Corresponding author: Anna Trojanowska, Department of Polish Academy of Sciences, Poland

Submission: 留 February 10, 2020

Published: 眥 February 19, 2020

Volume 4 - Issue 5

How to cite this article: Anna Trojanowska. Not Only on Bread and Water. The Nutrition of Prisoners in the Kingdom of Poland in the 19th Century. Nov Tech Nutri Food Sci. 4(5).NTNF.000598.2020. DOI: $10.31031 /$ NTNF.2020.04.000598

Copyright@ Anna Trojanowska. This article is distributed under the terms of the Creative Commons Attribution 4.0 International License, which permits unrestricted use and redistribution provided that the original author and source are credited.

\section{Short Communication}

At the turn of the $18^{\text {th }}$ and $19^{\text {th }}$ centuries, Europe saw the birth of prison reform. The repressive approach to prisoners underwent gradual changes. The penalty of the deprivation of liberty lost its character of revenge, was supposed to be educational and to serve social rehabilitation. Starvation as a deterrent to crime was considered too cruel. However, punishment had to be severe and acute, and poor diet was one way of mortifying the body. Therefore, the prisoners' diet was to meet the needs of physical workers, but at the same time it had to be unvarying and cheapest. It was modeled on a peasant diet, consisting mainly of plant products.

Prison reform was also introduced in Poland. In 1819 'The Prison Reform Project [1] was established in the Kingdom of Poland, and in 1823 'The Prison Instruction [2] regulating prison administration and economic affairs was published. It was recognized then that prisons should have such conditions that prisoners could preserve their moral and physical health. The food was supposed to be simple, easily digestible, but without spices, so as not to whet prisoners' appetite, because it was thought that light, homogeneous food made a man calm, obedient, capable of hard work and more resilient. Once a day prisoner got a warm meal called the Rumford soup consisting of interchangeably peas, cabbage, potatoes and buckwheat or barley groats, and additionally rye whole meal bread with salt and drinking water.

Depending on the type of prison (There were six types of detention centers in the Kingdom of Poland), various menus were used-the heavier the prison, the more severe and monotonous diet, deprived of meat, on some days deprived also of a hot meal. In a fortified prison in Zamość (in the Kingdom there was only one prison of this type), the Rumford soup was served for two days, and every third day only bread and water. The type of soup was changed once a week. In heavy prisons, the type of soup was changed every three days; on Friday prisoners only got bread and water. In lighter prisons, the soup was to be changed every day, and on holidays about 100 grams of meat per person was added to it. In all prisons, apart from a hot meal, daily portions of whole meal rye bread ( $0.8 \mathrm{~kg}$ for men, $0.6 \mathrm{~kg}$ for women), $6.5 \mathrm{~g}$ of salt and $13 \mathrm{~g}$ of lard (butter on fasting days, fat on other days) were issued. Another menu was provided for sick prisoners, nursing mothers, Jews, and sometimes political prisoners had a separate kitchen. The 1823 instruction had a number of additions and modifications, usually detrimental to prisoners [3]. In 1845 the amount of bread was reduced by $25 \%$, butter was removed from the diet of healthy prisoners, and oil was introduced; and the number of public holidays on which meat was served was limited to five a year. This change reduced the nutritional value of the diet (on average around 2234kcal) and contributed to the deterioration of prisoners' health.

In 1859 another 'Instruction for Penitentiary Institutions [4] had been introduced, and, with minor changes, stayed in force until the outbreak of the Great War. Meat was excluded from the menu, only bacon, oil or a bit of butter was envisaged as supplementations. Sour soup from flour, dumpling soup or gruel (portion approx. 0.5l) were prepared for breakfast for dinner-interchangeably: potatoes or sauerkraut, peas, and barley in various combinations. 
Prisoners got $0.6 \mathrm{~kg}$ of whole meal bread and $13 \mathrm{~g}$ of bacon (for Christians) par day, or on fasting days-oil; butter was provided for Jews. According to the calculations of one of the prison doctors, Leon Wernic, this diet contained on average: $111 \mathrm{~g}$ protein; fat 8g; carbohydrates 354g (about 3023kcal per day) and in terms of caloric content was insufficient for hard-working people [5]. It lacked meat, dairy and fat. It was also monotonous, which led to a loss of appetite. A similar diet was introduced in Prussian prisons, and meals were prepared in the form of unpalatable soups and gruel, which quickly caused aversion to food, and consequently led to the destruction of body and even the death of prisoners. After the introduction of more varied meals (more meat, cheese and fish were served), prisoners' mortality decreased.

In the Kingdom of Poland, when the nutrition tariff of 1866 was being prepared, the case was consulted with the Medical Council which proposed: limiting the amount of potatoes and replacing them with more valuable products (dumpling soup and cabbage with peas), increasing the daily bread ration to $0.8 \mathrm{~kg}$ for working prisoners; oil was to be replaced with butter; healthy prisoners were to receive meat ( $200 \mathrm{~g}$ twice a week). These changes were supposed to reduce the morbidity and mortality of prisoners, and thus also the expenses for medicine, but they increased the cost of food. Not all proposals came into existence. Only a new type of soup was introduced for breakfast-beetroot soup, and instead of potatoes, peas and cabbage were served once a week, as more nutritious and healthier. Prisoners demanded mainly fat, bought it for money earned in prison workshops, or asked doctors for oil [6].

The following years brought a further increase in food prices, which adversely affected the nutrition of prisoner's dependent on the treasury. However, in some prisons, including prisons in Kalisz, Piotrków and Łomża, efforts were made to enrich and diversify the diet-a small amount of meat was served three times a week; in the evening, hot water was given to the tea. The diet after changes contained more protein (121g animal protein, 19g vegetable), fat (20g) and carbohydrates (548g). Compared to the recommendations of 1859 , it was richer, but still insufficient for hard-working people,

To sum up, it can be said that, despite the changes in the approach to prisoners, the food of prisoners during the period was inadequate and monotonous. The doctors had little influence on the composition of the prison diet, and strictly calculated meals, delivered at particular time and in a specific mode, were one of the elements of the system of repression and disciplining prisoners, of preparing them to life in an ordered society. The health dimension of meals was a marginalized matter, subordinated to the idea of punishment and the economy of prison functioning.

\section{References}

1. Potocki K (1819) Projekt ogólnego i szczególnego polepszenia stanu i administracji więzień w Królestwie Polskim, Warsaw, Poland.

2. Potocki K (1819) Uwagi do projektu ogólnego i szczególnego ulepszenia administracji i stanu więzień publicznych w Królestwie Polskim, Warsaw, Poland.

3. (1823) Instrukcja więzienna, Warsaw, Poland.

4. Sobczak T (1984) Wyżywienie w zakładach penitencjarnych Królestwa Polskiego przed powstaniem styczniowym. In: Brykczyńska IR (Eds.), Z problematyki badań nad produkcją i konsumpcją żywności w Polsce. Studia i Materiały z Historii Kultury Materialnej, Warsaw, Poland, 57: 131-214.

5. (1859) Instrukcja dla zakładów karnych Królestwa Polskiego. Warsaw, Poland.

6. Wernic L (1907) Stan zdrowotny domów kary. Zdrowie 23(9): 691-737. 